\title{
MIR16-2 Pre-miRNA
}

National Cancer Institute

\section{Source}

National Cancer Institute. MIR16-2 Pre-miRNA. NCI Thesaurus. Code C82705.

MIR16-2 pre-miRNA is an oligoribonucleotide that is encoded by the human MIR16-2

gene and is involved in the regulation of gene expression. 